

Bioactive Compounds in Health and Disease

\title{
The effects of vitamin D on respiratory illnesses: a prospective natural treatment for COVID-19 symptoms
}

\section{Charlotte Giordano ${ }^{1 *}$ and Danik Martirosyan ${ }^{2}$}

${ }^{1}$ Concordia University, Irvine, CA, USA; ${ }^{2}$ Functional Food Center, Functional Food Institute, Dallas, TX, USA

${ }^{*}$ Corresponding Author: Charlotte Giordano, Functional Food Center. Functional Food Institute, Dallas, TX, USA

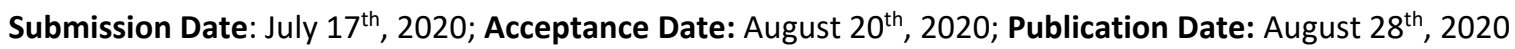

Please cite this article as: Giordano C., Martirosyan D. The effects of vitamin D on respiratory illnesses: a prospective natural treatment for COVID-19 symptoms. Bioactive Compoinds in Health and Disease 2020; 3(8):124-140 DOI:

https:/doi.org/10.31989/bchd.v3i8.734

\begin{abstract}
Background: In the midst of COVID-19, healthcare specialists and researchers worldwide have been actively investigating treatments for this new disease. As of July $3^{\text {rd }}, 2020$, there have been a total of $11,048,509$ confirmed cases in more than 188 countries and regions with more and more cases being identified every day. Though there have been a couple of medications given EUA status by the FDA such as chloroquine and hydroxychloroquine, remdesivir, and Fresenius Propoven, some of these treatments have been found to carry substantial health risks. Chloroquine and hydroxychloroquine, for example, were found to cause abnormal heart rhythms and facilitated higher rates of death among patients in clinical trials. For this reason, a more natural option such as vitamin D has the potential to be safer and more effective in the prevention of SARS-CoV-2 symptoms.

Objective: In this study, we investigate the benefits of vitamin D supplementation as shown in previous clinical trials involving respiratory illnesses and discussed which foods are most rich in vitamin D. Ultimately, we aim to provide an understanding of the mechanisms by which vitamin $D$ is acquired and the most effective amounts that
\end{abstract}


people should regularly consume in order to strengthen their immune system.

Methods: All of the case studies cited in this review were found through Google Scholar or NCBI by search queries such as "Vitamin D supplementation to treat respiratory illness." From over 48,000 results, we further searched for clinical trial studies on human subjects which had already been completed. Additional information regarding vaccinations and medications was sourced from the FDA and information about the nutritional value of foods was obtained from the USDA.

Results: Vitamin D has been shown to have many beneficial effects on patients suffering from both respiratory and non-respiratory illnesses. These benefits include, but are not limited to, lowered susceptibility to infection and lower bacterial counts, reduced symptoms of illness, increased serum $25(\mathrm{OH}) \mathrm{D}$, and corrected vitamin D deficiency.

Conclusions: Given the striking symptomatic, molecular, and pathological similarities between infection from SARS-CoV-2 and other respiratory illnesses such as influenza, the positive results from vitamin D supplementation suggest that vitamin D may be a viable prevention option for SARS-CoV-2 symptoms. Through the consumption of vitamin D-rich foods like UV-exposed mushrooms, salmon, and trout, low serum 25(OH)D levels could be corrected, and the reduction of symptoms could be naturally facilitated. Through the induction of cathelicidin and defensin, the regulation of cytokines, and the increased production of anti-microbial peptides, vitamin $D$ has the potential to act as a natural prevention option without adverse side-effects like those caused by chloroquine and other proposed drugs.

Keywords: Vitamin D; Deficiency; Respiratory IIIness; COVID-19; Influenza; Cathelicidin; Defensin; SARS-CoV-2; ACE2; ANG II.

CFFC 2020. This is an Open Access article distributed under the terms of the Creative Commons Attribution 4.0 License (http://creativecommons.org/licenses/by/4.0).

\section{INTRODUCTION}

\section{COVID-19 Spread and Treatment Options: On}

December 31st, 2019, multiple cases of pneumonia with an unknown origin were detected in Wuhan City located within the Hubei province of China. Originally called 2019-nCoV (abbreviation for 2019 novel coronavirus), the WHO renamed the infection COVID19 in February 2020, only a month before the declaration that COVID-19 was classified as a global pandemic. The pathogen that causes COVID-19 is called SARS-CoV-2. As of July 3rd, 2020, there have been a total of $11,048,509$ confirmed cases in over 188 countries and regions [1]. Coronaviruses are single-stranded RNA viruses enveloped by a surface covered in protein spikes called "corona" [2]. These coronas are integral for the virus because they act as the point of contact between the virus and ACE2 (angiotensin-converting enzyme) surface proteins of lung cells. These receptors are found on the surface of many types of cells including those that make up the lungs, heart, blood vessels, and intestines. Within the lungs, ACE2 receptors are very abundant on type 
II pneumocytes, one of the prominent cell types that line the alveoli [3]. The presence of ACE2 receptors on these cells and their contact with the external environment (through the absorption of oxygen and the release of carbon dioxide waste through the endothelium) helps to explain why SARS manifests mainly as a respiratory disease. Normally, ACE2 regulates blood pressure and wound healing as well as inflammation. This is done through the management of angiotensin II (ANG II) proteins which are known to facilitate damage to tissue linings through increases in inflammation and blood pressure [4]. Under normal conditions, ACE2 converts ANG II into ANG (1-7), which counteracts the activities of ANG II [5]. When the SARS-CoV-2 virus binds to these ACE2 receptors on the surface membrane of cells, it prevents the production of ACE2 and, therefore, facilitates an increase in ANG II allowing it to cause inflammation and damage. Although other tissues expressing ACE2 are damaged like the liver, kidneys, or heart, the primary location of injury by SARS-CoV-2 is the lungs. It has previously been shown that the demographic most at risk of contracting COVID-19 includes those who are older in age. This has been observationally correlated with the fact that serum $25(\mathrm{OH}) \mathrm{D}$ concentrations often decrease with age due to age-related declines in kidney function, less efficient vitamin D3 production due to skin thinning (less 7-dehydrocholesterol in the skin), and less time spent outdoors. In fact, it has been shown that the production of calcitriol $(1,25(\mathrm{OH}) 2 \mathrm{D})$ in the elderly is reduced by as much as $50 \%$ due to declines in renal function alone [6].

Due to the severity and longevity of the crisis, researchers have been working tirelessly on the development of vaccines and treatments to slow the pandemic. In April and May of 2020, the FDA announced emergency use authorization (EUA) for three medications to treat coronavirus: chloroquine and hydroxychloroquine (anti-malarial drugs), remdesivir (an anti-viral drug), and Fresenius Propoven (a drug used for sedation) [7]. Alongside these EUA drugs, there are a handful of other treatments being investigated from antivirals like arbidol to common medications like ibuprofen. However, there have been substantial health risks following the use of some of these manufactured drugs. Chloroquine and hydroxychloroquine, for example, were found to cause abnormal heart rhythms and, in clinical trials, patients treated with hydroxychloroquine died at a higher rate than other coronavirus patients [8]. The development of newer compounds to use in treatment would take much too long and would likely never make it to market in time to contain the spread of the pandemic. As such, drugs and treatments that already exist and have been previously studied are primarily being considered. While there are many drugs to be considered, some may have unexpected harmful effects and the clinical trials and regulation requirements for these treatments take a very long time to process. As of June 2020, upwards of 100 research groups have been in the process of developing coronavirus vaccinations, yet the estimations for their usage in the general population range from the beginning to the end of 2021 [9]. For this reason, many researchers are starting to turn towards the consideration of functional foods and their bioactive compounds in the search for more natural and readily available treatment options.

Since its first creation in 1984, the definition of functional foods has often been miscommunicated between scientists, manufacturers, and the public. In a recent article published by the Functional Food 
Center, a new definition for functional foods was created to strengthen this communication as well as standardize and legitimize the field of functional foods. According to the article, functional foods are "natural or processed foods that contain known or unknown biologically active compounds, which, in defined amounts, provide a clinically proven and documented health benefit for the prevention, management, or treatment of chronic disease" [10]. These biologically active compounds may be present in the form of flavonoids, chlorophylls, lipids, or even vitamins. With this paper, our intention is to undertake a review of pertinent recent and past research that supports the use of vitamin D as a viable means of preventing and treating the symptoms caused by the recent coronavirus infection. Although other natural compounds such as aescin [11], lycorine [12], and theaflavin [13] have been shown to have.

In a study done by Yang et al. [14], six groups of Wister rats with acute lung injury were randomly induced with either lipopolysaccharide (LPS), calcitriol $(25 \mu \mathrm{g} / \mathrm{kg})$, or one of three amounts of lipopolysaccharide and calcitriol $(1 \mathrm{u}-\mu / \mathrm{kg}, 5 \mu \mathrm{g} / \mathrm{kg}$, or $25 \mu \mathrm{g} / \mathrm{kg}$ ). It was found that clinical manifestations like rapid shallow breathing and oral/nose hemorrhage were obvious in the LPS group and much milder in the groups of rats with LPS and calcitriol. Additionally, the LPS and calcitriol groups had a significantly higher expression of vitamin $D$ receptor (VDR) mRNA and ACE2 mRNA ( $p<0.05)$ which was significantly lower than the rats in the control group $(p<0.05)$. These findings suggest that calcitriol increases the expression of VDR mRNA and ACE2 mRNA and that these increased expressions play a role in protection against acute lung injury development in these rat models. These results may also promisingly suggest a similar mechanism present in humans given the usage of Wistar rats in preclinical studies comparative to humans. This study acts as one of many examples exhibiting the beneficial effects that vitamin $D$ can have on managing and preventing symptoms of lung distress like those manifested in patients of COVID-19.

What is Vitamin D?: Vitamin D is present in two forms: vitamin $D_{2}$ and vitamin $D_{3}$. Vitamin $D_{2}$ is produced by both, fungi and yeast, when they are exposed to UV light. When the yeast sterol ergosterol is exposed to UV light, it is converted from its provitamin form into vitamin $D_{2}$ [15]. For this reason, vitamin $D_{2}$ is naturally found most often in sunexposed mushrooms and lichen. Vitamin $D_{3}$ is the variant we produce in our skin upon exposure to ultraviolet-B (UVB) light or the consumption of foods that contain vitamin $D_{3}[16]$. When vitamin $D_{3}$ is ingested or produced as a result of UVB exposure contacting 7-dehydrocholesterol in the skin, it is in a biologically inert form that needs to be hydroxylated in the liver before it can be used by the body [17]. Within the liver, D-25-hydroxylase (25-OHase) converts this inert form of vitamin D into $25(\mathrm{OH}) \mathrm{D}$ and subsequent processing in the kidneys by $25(\mathrm{OH}) \mathrm{D}-1-$ OHase (CYP27B1) converts this product to calcitriol $(1,25(\mathrm{OH}) 2 \mathrm{D})$, the biologically active form of vitamin D. This active form binds to the VDR and behaves as a transcription factor in the nucleus of the target cells [18]. One of the most well-known roles of vitamin D includes its ability to stimulate intestinal calcium absorption and phosphorus uptake, thereby regulating calcium metabolism. Without the help of calcitriol, only $10-15 \%$ and $60 \%$ of calcium and phosphorus would be absorbed, respectively [19].

Vitamin $D$ has recently been identified as a pleiotropic hormone due to its simultaneous anti- 
inflammatory, antioxidant, and neuroprotective properties [20]. These capabilities also point towards the influence of vitamin $D$ on innate and acquired immune reactions. When the active form of vitamin D, calcitriol, binds to VDRs, it is brought to the nucleus where it behaves as a transcription factor controlling gene expression [4]. Many of these mechanisms activated by vitamin D pertain to the vitamin's involvement in the innate immune system. Some such mechanisms include the induction of cathelicidin and defensin, the regulation of cytokine release, and the increased production of anti-microbial peptides that fight against bacteria.

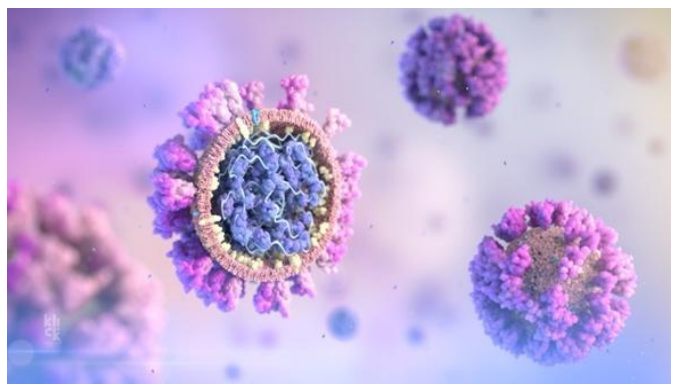

Figure 1. This 3D model depicts SARS-CoV-2 and showcases the pink protein spikes, called "corona," found on the surface of the virus. Image acquired from Klick Health [18].

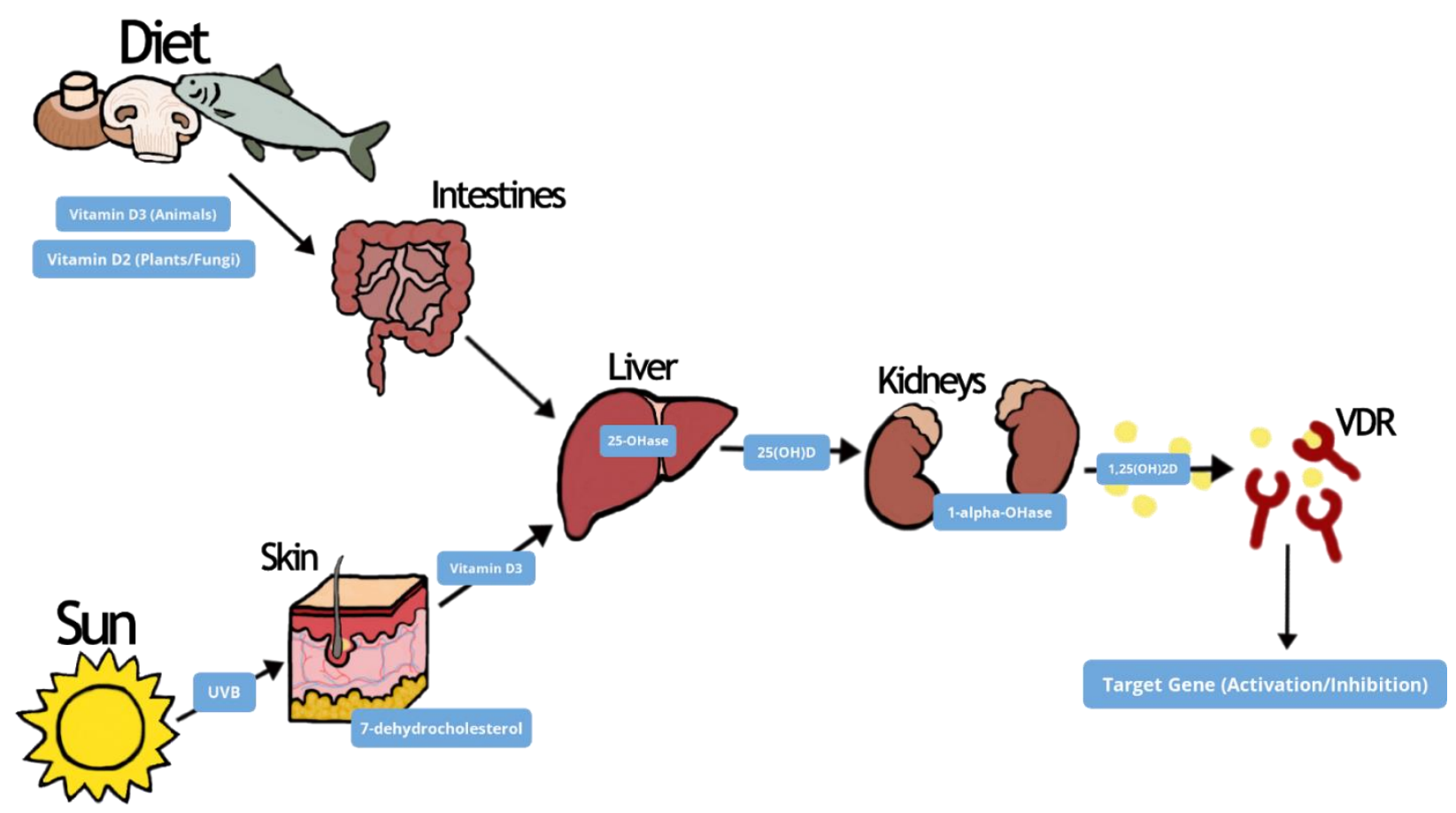

Figure 2. This figure shows the mechanisms by which vitamin $D_{2}$ and vitamin $D_{3}$ are transported into the body, converted into usable bioactive forms, and interact with the genes in target tissues. This figure was created by the author as referenced by [19] and [20].

\section{METHODS}

For the five initial studies presented in Table 1, searches were made in NCBI or Google Scholar such as "Vitamin D supplementation to treat illness." These studies [32-33] were chosen to represent the diversity of illnesses that vitamin $D$ is capable of managing. Of the more than 48,000 results, we then specifically chose studies that were conducted as clinical trials and included detailed data for $25(\mathrm{OH}) \mathrm{D}$ or anti-microbial peptide concentrations. The subsequent studies [39-47] in Table 2 were chosen specifically to represent the effects of vitamin $D$ on respiratory illnesses. Our search in the aforementioned databases were more similar to "Vitamin D supplementation to treat respiratory illness" or "Vitamin D supplementation to treat 
SARS." After searching extensively through these databases and reviewing the prospective studies, we ended up with a total of 14 case studies, as represented in Table 1 and Table 2.

\section{DISCUSSION}

\section{Protective Mechanisms of Vitamin D}

Increased Production of Anti-Microbial Peptides:

One mechanism vitamin $D$ utilizes to boost innate immunity involves the facilitation of anti-microbial peptide (AMP) production. This entails the induction of cathelicidin and defensin, the two largest types of antimicrobial proteins in mammals [24]. Cathelicidin lowers viral replication rates by binding to and neutralizing the lipopolysaccharide cell membranes of invading pathogens, killing them and preventing the biological activity of their endotoxins [25]. The inactive precursors to these antimicrobial peptides (called propeptides) are stored in neutrophil granules and released as mature peptides in response to leukocyte activation [26]. These peptides are also part of a larger class of cationic peptides that are amphophilic, allowing them to permeate the membranes of foreign pathogens in the body [27].

Defensin is another essential component of innate immunity that protects against infection. These peptides are mainly produced by neutrophils and epithelial cells and those found in the lungs are denoted by subtypes $\alpha$ - and 6 -. These proteins have the ability to induce the chemotaxis of immune cells, reduce inflammation, and partake in wound repair. Additionally, defensin inhibits influenza infection by preventing the membrane fusion of viral hemagglutinin [28].

Regulation of Cytokine Release: Vitamin D has also been shown to reduce inflammation by regulating the release of cytokines within the body and the reduction of pro-inflammatory cytokines that injure the lining of the lungs [30]. Cytokines are a large category of signaling proteins that are secreted by cells in the immune system and regulate immunity, inflammation, and hematopoiesis [26]. The COVID-19 patients in China were found to have high levels of cytokines including GCSF, MIP1A, and FNF $\alpha$ which respectively stimulate the survival of neutrophil precursors, support immune responses toward infection and inflammation, and facilitate inflammatory responses [30]. In worsened cases of COVID-19, patients were observed to have cytokine storms. A cytokine storm is an uncontrolled release of proinflammatory cytokines that are associated with a variety of infectious and noninfectious diseases. This overactivation of the adaptive immune system produced high levels of cytokines that have the potential to cause complications like severe pneumonia, acute kidney failure, or acute heart failure [31]. When vitamin $D$ is consumed, the innate immunity is boosted, reducing the viral load and suppressing the adaptive immune system. This mechanism allows vitamin $D$ to ameliorate the negative effects of cytokine storms and reduce harmful symptoms caused by the associated inflammation and infection.

Respiratory IIInesses and COVID-19: Conditions are commonly categorized as either acute or chronic in their onset. An acute condition is a sudden illness for which symptoms develop quickly and often require medical intervention. A chronic condition, however, is an illness with symptoms that worsen over time and last for more than half a year. Respiratory tract infections are classified as conditions that specifically 
Table 1. A broad overview of illnesses capable of being managed by vitamin D

\begin{tabular}{|c|c|c|c|c|}
\hline Illness & Participants & Administered Dosage & Results & Reference \\
\hline $\begin{array}{l}\text { Atopic Dermatitis } \\
\text { (AD) }\end{array}$ & $\begin{array}{l}14 \text { controls and } 14 \\
\text { atopic patients. }\end{array}$ & $\begin{array}{l}4,000 \text { IU per day of } \\
\text { oral vitamin } D_{3} \\
\text { (cholecalciferol) was } \\
\text { given for } 21 \text { days. }\end{array}$ & $\begin{array}{l}\text { - The expression of } \\
\text { cathelicidin increased } \\
\text { from a median of } 3.53 \\
\text { relative copy units } \\
\text { (RCU) before } \\
\text { supplementation to a } \\
\text { median of } 23.91 \text { RCU } \\
\text { post- } \\
\text { supplementation. } \\
\text { - Those with normal } \\
\text { skin showed an } \\
\text { increase from a } \\
\text { median of } 1.0 \text { RCU to } \\
1.78 \text { RCU ( } p>0.05 \text { ), } \\
\text { whilst AD non-lesional } \\
\text { skin mildly increased } \\
\text { from a median value } \\
\text { of } 1.50 \text { RCU to } 1.75 \\
\text { RCU post } \\
\text { supplementation. }\end{array}$ & {$[32]$} \\
\hline Crohn's Disease (CD) & $\begin{array}{l}27 \text { CD patients in } \\
\text { remission; } 14 \text { people } \\
\text { assigned placebo and } \\
13 \text { received the active } \\
\text { treatment. }\end{array}$ & $\begin{array}{l}2,000 \mathrm{IU} / \text { day of } \\
\text { vitamin D or placebo } \\
\text { for } 3 \text { months. }\end{array}$ & $\begin{array}{l}\text { - At three months, } \\
25(\mathrm{OH}) \mathrm{D} \\
\text { concentrations were } \\
\text { significantly higher in } \\
\text { the vitamin } \mathrm{D} \text { treated } \\
\text { group ( } 91.6 \text { ( } 75.5 \text { - } \\
107.6) \mathrm{nmol} / \mathrm{L}) \\
\text { compared to the } \\
\text { placebo group ( } 40.4 \\
\text { (30.4-50.4) nmol/L). } \\
\text { - The treatment was } \\
\text { sufficient to raise the } \\
25(\mathrm{OH}) \mathrm{D} \\
\text { concentrations to } \geq 75 \\
\text { nmol/L in } 8 / 12 \text { of the } \\
\text { participants treated in } \\
\text { the winter. }\end{array}$ & [33] \\
\hline $\begin{array}{l}\text { Chronic Kidney } \\
\text { Disease (CKD) }\end{array}$ & $\begin{array}{l}\text { Participants with CKD } \\
\text { stage } 3 \text { and } 4 \\
\text { (estimated glomerular } \\
\text { filtration rate, } 15-59 \\
\mathrm{~mL} / \mathrm{min} / 1.73 \mathrm{~m}^{2} \text { ), } \\
\text { vitamin } \mathrm{D} \text { insufficiency } \\
(\text { serum } 25(\mathrm{OH}) \mathrm{D}<30 \\
\mathrm{ng} / \mathrm{mL} \text { ), and serum } \\
\text { intact parathyroid } \\
\text { hormone levels }>70 \\
\mathrm{pg} / \mathrm{mL} \text {. } 10 \text { patients } \\
\text { received } \\
\text { cholecalciferol and } 10 \\
\text { received placebo. }\end{array}$ & $\begin{array}{l}\text { Randomly assigned to } \\
\text { receive either } 50,000 \\
\text { IU of cholecalciferol or } \\
\text { placebo once weekly } \\
\text { for } 12 \text { weeks. }\end{array}$ & $\begin{array}{l}\text { - } 9 / 10 \text { subjects that } \\
\text { received } \\
\text { cholecalciferol } \\
\text { treatment became } \\
\text { vitamin } \mathrm{D} \text { sufficient } \\
\text { (serum } \geq 30 \mathrm{ng} / \mathrm{mL} \text { ) } \\
\text { within } 6 \text { weeks of } \\
\text { supplementation. } \\
\text { - After } 12 \text { weeks of } \\
\text { therapy, participants } \\
\text { supplemented with } \\
\text { cholecalciferol had an } \\
\text { average increase of } \\
\text { 185\% in serum } \\
25(O H) D \\
\text { concentrations } \\
\text { compared with an } \\
\text { average increase of }\end{array}$ & [34] \\
\hline
\end{tabular}




\begin{tabular}{|c|c|c|c|c|}
\hline & & & $\begin{array}{l}5 \% \text { in the placebo } \\
\text { group. }\end{array}$ & \\
\hline $\begin{array}{l}\text { Fractures and } \\
\text { Mortality }\end{array}$ & $\begin{array}{l}2,686 \text { people }(2,037 \\
\text { men and } 649 \text { women) } \\
\text { aged } 65 \text { years and } \\
\text { over. }\end{array}$ & $\begin{array}{l}100,000 \text { IU oral } \\
\text { vitamin } D_{3} \\
\text { (cholecalciferol) } \\
\text { supplementation or } \\
\text { matching placebo } \\
\text { every four months } \\
\text { over five years. }\end{array}$ & $\begin{array}{l}\text { - Total fracture } \\
\text { incidence was } \\
\text { reduced by } 22 \% \text { and } \\
\text { fractures in major } \\
\text { osteoporotic sites by } \\
33 \% \text {. } \\
\text { - The relative risk of } \\
\text { mortality in the } \\
\text { vitamin } D \text { group was } \\
0.88 \text { ( } 0.746 \text { to } 1.06 \text { ) as } \\
\text { compared to the } \\
\text { placebo. }\end{array}$ & [35] \\
\hline Cancer & $\begin{array}{l}1,179 \text { community- } \\
\text { dwelling women } \\
\text { randomly selected } \\
\text { from a population of } \\
\text { healthy } \\
\text { postmenopausal } \\
\text { women aged }>55 \\
\text { years. }\end{array}$ & $\begin{array}{l}\text { Randomly assigned to } \\
\text { receive } 1,400-1,500 \\
\text { mg of supplemental } \\
\text { calcium alone }(\mathrm{Ca}), \\
\text { supplemental calcium } \\
\text { plus } 1,100 \text { IU vitamin } \\
D_{3}(\mathrm{Ca}+\mathrm{D}) \text {, or placebo. }\end{array}$ & $\begin{array}{l}\text { - Decreased all cancer } \\
\text { risk correlated with } \\
\text { improved vitamin D } \\
\text { status } \\
\text { - The relative risk (RR) } \\
\text { of developing cancer } \\
\text { at the end of the } \\
\text { study was } 0.402 \text { for } \\
\text { the Ca+D group and } \\
0.532 \text { for the Ca } \\
\text { group. After one year, } \\
\text { the RR for the Ca+D } \\
\text { group dropped to } \\
0.232 \text { and the others } \\
\text { remained unchanged. }\end{array}$ & [36] \\
\hline
\end{tabular}

affect the air passages and may be acute or chronic. This definition includes acute infections affecting the lower respiratory tract and lungs such as influenza, acute respiratory distress syndrome (ARDS), and pneumonia. Chronic respiratory illnesses can range in severity from asthma to chronic obstructive pulmonary disease (COPD) to lung cancer [37]. Despite the categorical differences between respiratory illnesses, many of them share similar causes and symptoms. These symptoms typically begin with difficulty breathing, a chronic cough, chest pain, fever, and fatigue, but they may worsen over time.

In humans, coronaviruses have a wide range of effects from mild infections of the upper respiratory tract to more serious infections of the lower respiratory tract. The more severe infections can present themselves as illnesses like pneumonia, severe acute respiratory syndrome (SARS), or the current novel coronavirus, COVID-19. SARS-CoV-2 is the name of the pathogen which causes COVID-19. This name was chosen due to the virus' resemblance to SARS-CoV, which caused the SARS outbreak from 2002-2004. While COVID-19 can cause pneumonia, ARDS, and other severe lung conditions, people with pre-existing conditions such as COPD are much more likely to develop severe, life-threatening symptoms. For this reason, our analysis of vitamin D supplementation effectiveness features a wide variety of respiratory illness clinical trials. The results of these clinical trials as well as the administered dosage of vitamin $D$, the participants chosen for the trial, and the illness being treated can be seen in Table 2. For example, sequencing of the COVID-19 motif that contacts ACE2 and the receptor-binding domain has revealed incredibly close similarities to SARS-CoV. 
Table 2. An overview of respiratory illnesses manageable by vitamin $D$, including the dosage of vitamin $D$ supplemented and the results of supplementation

\begin{tabular}{|c|c|c|c|c|}
\hline Illness & Participants & Administered Dosage & Results & Reference \\
\hline Respiratory Infections & $\begin{array}{l}70 \text { patients per } \\
\text { treatment arm; } 70 \\
\text { patients receiving } \\
\text { vitamin } D_{3} \\
\text { supplementation and } 70 \\
\text { receiving placebo. }\end{array}$ & $\begin{array}{l}\text { Randomized to } \\
\text { receive } 12 \text { months of } \\
\text { treatment with } \\
\text { vitamin } \mathrm{D}_{3} \text { (Vigantol, } \\
4,000 \mathrm{IU} / \text { day) or } \\
\text { placebo oil. }\end{array}$ & $\begin{array}{l}\text { - One year of vitamin } \\
D_{3} \text { treatment was } \\
\text { correlated with a } \\
\text { reduced total } \\
\text { infectious score. } \\
\text { - The vitamin } \mathrm{D}_{3} \\
\text { group had } 76 \text { positive } \\
\text { microbiological } \\
\text { (bacteria or fungi) } \\
\text { findings and the } \\
\text { placebo group had } \\
159 \text {. }\end{array}$ & [39] \\
\hline Respiratory Infections & $\begin{array}{l}40 \text { participants; } 21 \\
\text { vitamin } D_{3} \text { and } 19 \\
\text { placebo. }\end{array}$ & $\begin{array}{l}\text { Received either } \\
\text { vitamin } D_{3}(1,000 \\
\text { IU/day, } 90,000 \mathrm{IU} \\
\text { total) or matching } \\
\text { placebo for } 90 \text { days. }\end{array}$ & $\begin{array}{l}\text { - Most participants } \\
\text { had } 25(\mathrm{OH}) \mathrm{D}_{3} \text { levels } \\
\text { less than } 40 \mathrm{ng} / \mathrm{mL} \\
\text { and only those taking } \\
\text { vitamin } \mathrm{D} \\
\text { proportionally } \\
\text { increased their } \\
\text { baseline levels. } \\
\text { - Subjects } \\
\text { supplemented with } \\
\text { vitamin } \mathrm{D} \text { for } 90 \text { days } \\
\text { had significantly } \\
\text { lower live bacteria in } \\
\text { relative light units } \\
\text { compared with their } \\
\text { baseline. }\end{array}$ & [40] \\
\hline $\begin{array}{l}\text { Acute Respiratory } \\
\text { Infection }\end{array}$ & $\begin{array}{l}164 \text { Finnish men } 18-28 \\
\text { years of age; } 80 \\
\text { received vitamin D } \\
\text { supplementation and } 84 \\
\text { received placebo. }\end{array}$ & $\begin{array}{l}\text { The intervention } \\
\text { group received } 400 \mathrm{IU} \\
(10 \mu \mathrm{g}) \text { vitamin } \mathrm{D}_{3} \text { and } \\
\text { the control group } \\
\text { received placebo. }\end{array}$ & $\begin{array}{l}\text { - After } 6 \text { months, the } \\
\text { mean serum } 25(\mathrm{OH}) \mathrm{D} \\
\text { concentrations were } \\
71.6 \pm 22.9 \mathrm{nmol} / \mathrm{L} \text { in } \\
\text { the intervention } \\
\text { group and } 51.3 \pm 15.5 \\
\mathrm{nmol} / \mathrm{L} \text { in the placebo } \\
\text { group. } \\
\text { - The hazard ratio for } \\
\text { absence from duty } \\
\text { due to respiratory } \\
\text { tract infection was } \\
\text { lower in the vitamin } \mathrm{D} \\
\text { group than the } \\
\text { control. }\end{array}$ & [41] \\
\hline Tuberculosis & $\begin{array}{l}131 \text { patients with } \\
\text { tuberculosis; } 64 \\
\text { received placebo and } 67 \\
\text { received vitamin } D .\end{array}$ & $\begin{array}{l}\text { A single dose of } \\
100,000 \text { IU of vitamin } \\
D_{3} .\end{array}$ & $\begin{array}{l}\text { - Induced a 91\% } \\
\text { increase in mean } \\
\text { serum } 25(\mathrm{OH}) \mathrm{D} \text { from } \\
35.2 \mathrm{nmol} / \mathrm{L} \text { pre- } \\
\text { supplementation to } \\
67.4 \mathrm{nmol} / \mathrm{L} \text { after } \\
\text { - Corrected deficiency } \\
\text { in all } 23 \text { patients in } \\
\text { the intervention arm } \\
\text { with baseline serum } \\
25(\mathrm{OH}) \mathrm{D}<20 \mathrm{nmol} / \mathrm{L} \text {. }\end{array}$ & {$[42]$} \\
\hline
\end{tabular}




\begin{tabular}{|c|c|c|c|c|}
\hline Pneumonia & $\begin{array}{l}453 \text { children } 1-36 \\
\text { months old diagnosed } \\
\text { with non-severe or } \\
\text { severe pneumonia; } 224 \\
\text { received vitamin } D_{3} \text { and } \\
229 \text { received placebo. }\end{array}$ & $\begin{array}{l}460 \text { placebo and } \\
100,000 \mathrm{IU} \text { of vitamin } \\
\mathrm{D}_{3} \text { doses in } 1 \mathrm{~mL} \text { of } \\
\text { olive oil were sealed } \\
\text { in identical } 2 \mathrm{~mL} \\
\text { plastic syringes. }\end{array}$ & $\begin{array}{l}\text { - The risk of children } \\
\text { having repeat } \\
\text { episodes of } \\
\text { pneumonia during the } \\
\text { 90-day post- } \\
\text { treatment period was } \\
\text { significantly lower in } \\
\text { the vitamin D group } \\
\text { than the placebo } \\
\text { group. }\end{array}$ & [43] \\
\hline $\begin{array}{l}\text { Chronic Obstructive } \\
\text { Pulmonary Disease } \\
\text { (COPD) }\end{array}$ & $\begin{array}{l}182 \text { patients with } \\
\text { moderate to severe } \\
\text { COPD. }\end{array}$ & $\begin{array}{l}\text { 100,000 IU of vitamin } \\
\text { D supplementation or } \\
\text { placebo every } 4 \\
\text { weeks for } 1 \text { year. }\end{array}$ & $\begin{array}{l}\text { - Mean serum } \\
25(\mathrm{OH}) \mathrm{D} \text { increased } \\
\text { significantly in the } \\
\text { vitamin } \mathrm{D} \text { group } \\
\text { compared to the } \\
\text { placebo group (mean } \\
\text { difference } 30 \mathrm{ng} / \mathrm{mL}) \text {. } \\
\text { - Participants in the } \\
\text { vitamin } \mathrm{D} \text { group with } \\
\text { severe vitamin } \mathrm{D} \\
\text { deficiency ( }<10 \\
\text { ng/mL) at baseline } \\
\text { showed a significant } \\
\text { reduction in } \\
\text { exacerbations of } 43 \% \text {. }\end{array}$ & [44] \\
\hline $\begin{array}{l}\text { Chronic Obstructive } \\
\text { Pulmonary Disease } \\
\text { (COPD) }\end{array}$ & $\begin{array}{l}240 \text { patients; } 122 \text { in the } \\
\text { vitamin } D_{3} \text { group and } \\
118 \text { in the placebo } \\
\text { group. }\end{array}$ & $\begin{array}{l}\text { Received six } 2- \\
\text { monthly oral doses of } \\
3 \mathrm{mg} \text { of vitamin } \mathrm{D}_{3} \text { or } \\
\text { placebo over one } \\
\text { year. }\end{array}$ & $\begin{array}{l}\text { - Vitamin } \mathrm{D}_{3} \text { was } \\
\text { protective against } \\
\text { moderate/severe } \\
\text { exacerbation in } \\
\text { participants with } \\
\text { baseline serum } \\
25(\mathrm{OH}) \mathrm{D} \\
\text { concentrations }<50 \\
\text { nmol/L. }\end{array}$ & [45] \\
\hline Influenza & $\begin{array}{l}208 \text { African-American } \\
\text { post-menopausal } \\
\text { women were } \\
\text { randomized to receive } \\
\text { vitamin } D_{3}(n=104) \text { or } \\
\text { placebo }(n=104) \text {. }\end{array}$ & $\begin{array}{l}\text { After } 2 \text { years, the } \\
\text { vitamin } D_{3} \text { dose was } \\
\text { increased to } 50 \mu \mathrm{g} / \mathrm{d} \\
(2,000 \mathrm{IU}) \text { in the } \\
\text { active group. }\end{array}$ & $\begin{array}{l}\text { - After } 3 \text { years, } 34 \\
\text { patients reported cold } \\
\text { and influenza } \\
\text { symptoms; } 8 \text { in the } \\
\text { vitamin } D_{3} \text { group and } \\
26 \text { in the placebo } \\
\text { group. } \\
\text { - Vitamin D } \\
\text { supplementation } \\
\text { (particularly at higher } \\
\text { doses) was shown to } \\
\text { protect against typical } \\
\text { influenza seeing as } \\
\text { only one subject had } \\
\text { influenza while } \\
\text { treated with } 50 \\
\mu g / \text { day. }\end{array}$ & {$[46]$} \\
\hline Seasonal Influenza A & $\begin{array}{l}430 \\
\text { schoolchildren/parent } \\
\text { pairs were randomly } \\
\text { assigned to treatment; } \\
217 \text { vitamin D and } 213 \\
\text { placebo. }\end{array}$ & $\begin{array}{l}\text { One tablet contained } \\
200 \text { IU vitamin } D_{3} \text { or } \\
\text { placebo. Participants } \\
\text { were asked to take } 3 \\
\text { tablets twice daily for } \\
\text { a total of } 1,200 \text { IU of } \\
\text { vitamin } D_{3} \text { daily or } \\
\text { placebo. }\end{array}$ & $\begin{array}{l}\text { Influenza A occurred } \\
\text { in } 18 \text { of } 167(10.8 \%) \\
\text { children receiving } \\
\text { vitamin } D_{3} \text { compared } \\
\text { with } 31 \text { of } 167 \\
(18.6 \%) \text { children } \\
\text { receiving placebo. }\end{array}$ & [47] \\
\hline
\end{tabular}


This similarity suggests that COVID-19, like SARS-CoV, utilizes the ACE2 receptor during infection. Vitamin D has previously been shown to prevent ANG ॥ accumulation and decrease harmful inflammatory activity [38]. Such evidence that vitamin D has beneficial effects on the symptoms of other respiratory illnesses may provide a stronger case for the potential benefits of vitamin $D$ in the treatment of COVID-19.

Influenza: Influenza is a viral disease that targets the upper and lower respiratory tract. Although COVID19 and influenza are caused by different viruses, they have very similar symptoms and effects. Both illnesses may include symptoms such as fever, shortness of breath, fatigue, body aches, or sore throat. Additionally, complications caused by both diseases include pneumonia, respiratory failure, inflammation of the heart, brain, or muscles, and multiple-organ failure. Influenza is characterized mainly by acute neutrophil infiltration as well as the narrowing of bronchioles. There are four types of influenza viruses: $A, B, C$, and D. Influenza $A$ and $B$ are the variations responsible for annual epidemics and are characterized by a combination of hemagglutinin and neuraminidase proteins present on the surface of the viruses [48]. The ability of vitamin D to upregulate the expression of anti-microbial peptides is especially relevant because these peptides can exhibit anti-viral activity. The main mechanism of cathelicidin in the immune system response involves the degradation of foreign pathogen envelope proteins; this is particularly effective for defense against influenza because the influenza virus has envelope proteins, making it more susceptible to this mechanism.
Acute Respiratory Infections: Tuberculosis is an acute respiratory infection initiated by Mycobacterium tuberculosis which enters the body and comes into contact with macrophages and dendritic cells. These cells activate $T$ cells with specialized $M$. tuberculosis antigens facilitating the growth of the pathogen [49]. As the pathogen continues to grow, it activates inflammatory responses and the apoptosis of macrophages, which can cause severe tissue damage [50]. This damage leads to symptoms such as coughing that lasts more than three weeks, chest pain, coughing up blood, and fatigue. Just one oral dose of $2.5 \mathrm{mg}$ of vitamin $\mathrm{D}$ has been shown to significantly enhance the ability of a person's whole blood to restrict mycobacterial growth [42]. When $M$. tuberculosis comes into contact with the TLR2/1 dimer on macrophages, both CYP27b1 (which facilitates the conversion of vitamin $D$ into its bioactive form, calcitriol) and VDR [51]. The cathelicidin gene is induced by this CYP27b1 and thus encodes for the AMP LL-37, which leads to the LL-37mediated destruction of M. tuberculosis [52].

Pneumonia is a lower respiratory infection caused by a number of different organisms including bacteria, viruses, or fungi such as Legionella, Mycoplasma, or Chlamydia. At the end of the bronchioles in the human body, there are small sacs called alveoli. These sacs are the site of gas exchange in the lungs where oxygen is exchanged for the carbon dioxide waste that we breathe out. When infected and disturbed by foreign organisms, the lung parenchyma (which alveoli are composed of) becomes inflamed, causing the alveoli to fill with pus and fluid. This inflammation is caused by the resident macrophages located in the lungs which engulf foreign pathogens and trigger cytokines such as IL-8 and IL-15 which facilitate the introduction of 
inflammatory cells (such as neutrophils) to the lungs [53]. When the alveoli become inflamed, patients experience coughing with phlegm, shortness of breath, and a fever, among other symptoms. Like with COVID-19, pneumonia is most serious for young children, people over the age of 65 , and those with weakened immune systems. Vitamin D lowers viral replication rates and regulates the release of cytokines, effectively reducing inflammation and reducing symptoms.

Foods Rich in Vitamin D: There are many varying recommendations for the amount of vitamin $D$ that people should consume daily but, as represented in Table 2, the National Institutes of Health (NIH) has created standard Recommended Daily Allowances (RDA) based on age. These values representatively show that, as previously discussed, older adults require more supplementation with vitamin $D$ due to their decreased serum 25(OH)D concentrations. The general amount of vitamin D necessary for those aged 1-70, however, stays consistently at 600 IU per day. Vitamin $D$ deficiency has been defined by a committee of the Institute of Medicine (IOM) as serum 25(OH)D levels lower than $20 \mathrm{ng} / \mathrm{mL}$, but greater than $10 \mathrm{ng} / \mathrm{mL}$ [54].

Table 3. Recommended daily allowances (RDA) for vitamin D based on age [54]

\begin{tabular}{|l|l|}
\hline Life Stage & Recommended \\
\hline Birth-12 months & $400 \mathrm{IU}(10 \mu \mathrm{g})$ \\
\hline Children, 1-13 years & $600 \mathrm{IU}(15 \mu \mathrm{g})$ \\
\hline Teens, 14-18 years & $600 \mathrm{IU}(15 \mu \mathrm{g})$ \\
\hline Adults, 19-70 years & $600 \mathrm{IU}(15 \mu \mathrm{g})$ \\
\hline Pregnant and Breastfeeding Women & $600 \mathrm{IU}(15 \mu \mathrm{g})$ \\
\hline Adults, 71+ years & $800 \mathrm{IU}(20 \mu \mathrm{g})$ \\
\hline
\end{tabular}

For this reason, researchers have been able to make a rough estimate for the amount of vitamin $D$ necessary at certain ages and in certain environmental conditions. The estimates for RDA in Table 3 were made under the assumption that these demographics were receiving minimal sun exposure. This is important because UV radiation exposure from the sun is a large source of vitamin D and is also highly variable based on geographic location and lifestyle. For example, people living in extreme northern and southern latitudes will get less vitamin $D$ in the winter, whereas those living closer to the equator will receive a more consistent amount of vitamin $D$ throughout the year.

Despite the RDAs set by the IOM, there is still debate over whether the RDA for vitamin D should be higher. In a study by Aloia et al. involving healthy adults, it was shown that a daily intake of 1,120-1,680 IU of vitamin D was necessary to maintain sufficient serum $25(\mathrm{OH}) \mathrm{D}$ levels of $30 \mathrm{ng} / \mathrm{mL}$. Furthermore, it was found that some individuals who were deficient in vitamin D needed supplementation of as much as $5,000 \mathrm{IU}$ in order to reach serum $25(\mathrm{OH}) \mathrm{D}$ levels of 30 $\mathrm{ng} / \mathrm{mL}$ [55]. This study, alongside others, presents evidence showing that 600 IU per day may not be a suitable amount for maintaining sufficient vitamin D levels. Because vitamin D deficiency can lead to such adverse effects as previously discussed and healthy serum levels of vitamin D maintain immune system health, it is important to have sufficient serum 25(OH)D levels. Although the IMO defined the upper levels of harmless vitamin D intake around 4,000 IU, 
toxicity or overdose from vitamin D intake is extremely rare. Even consumption of up to 10,000 IU per day has been shown not to cause harm to healthy individuals, however, the consumption of this much vitamin $D$ is very unnecessary [56]. There are many foods that are rich in vitamin D which can help to naturally supplement vitamin D through their incorporation into a healthy diet as shown in Table 4. In the summer, exposure to strong sun for as little as 5-30 minutes during midday can be sufficient to meet daily requirements for individuals with lighter skin. However, it is still necessary to consume sufficient levels of vitamin D, for example, in the winter when sunlight is a less reliable source of vitamin D [57].

Table 4. Foods rich in vitamin $D$ and the percentage of a standard (600 IU/day) recommended daily allowance (RDA) they fulfill [58]

\begin{tabular}{|c|c|c|c|c|}
\hline Food & Standard Portion & $\begin{array}{l}\text { Vitamin } D\left(D_{2}+D_{3}\right) \text { in } \\
\text { Standard Portion }(\mu \mathrm{g})\end{array}$ & $\begin{array}{l}\text { Vitamin } D\left(D_{2}+D_{3}\right) \text { in } \\
\text { Standard Portion (IU) }\end{array}$ & $\begin{array}{l}\text { Percent of } \\
\text { Recommended Daily } \\
\text { Allowance (Age 1-70) }\end{array}$ \\
\hline $\begin{array}{l}\text { Mushrooms, white, } \\
\text { exposed to ultraviolet } \\
\text { light, raw }\end{array}$ & 1 cup, whole (96 g) & 25.2 & 1008 & $168 \%$ \\
\hline $\begin{array}{l}\text { Salmon, sockeye, } \\
\text { canned }\end{array}$ & $3 \mathrm{oz}(85 \mathrm{~g})$ & 17.9 & 716 & $120 \%$ \\
\hline $\begin{array}{l}\text { Fish, trout, rainbow, } \\
\text { farmed, cooked }\end{array}$ & $3 \mathrm{oz}(85 \mathrm{~g})$ & 16.2 & 645 & $108 \%$ \\
\hline $\begin{array}{l}\text { Mushrooms, } \\
\text { portabella, exposed to } \\
\text { ultraviolet light, } \\
\text { grilled }\end{array}$ & 1 cup, sliced (121 g) & 15.9 & 634 & $106 \%$ \\
\hline $\begin{array}{l}\text { Salmon, sockeye, } \\
\text { cooked }\end{array}$ & $3 \mathrm{oz}$ (85 g) & 14.2 & 568 & $95 \%$ \\
\hline Swordfish, cooked & $3 \mathrm{oz}(85 \mathrm{~g})$ & 14.1 & 564 & $94 \%$ \\
\hline Fish oil, cod liver & 1 teaspoon (4.5 g) & 11.2 & 450 & $75 \%$ \\
\hline Tuna, canned, oil pack & 1 can $(6.5 \mathrm{oz})$, drained & 10.7 & 428 & $71 \%$ \\
\hline $\begin{array}{l}\text { Fortified cheese, } \\
\text { pasteurized process, } \\
\text { American }\end{array}$ & $\begin{array}{l}1 \text { cup, shredded (113 } \\
\text { g) }\end{array}$ & 8.48 & 340 & $57 \%$ \\
\hline $\begin{array}{l}\text { Oatmeal, regular or } \\
\text { quick, made with milk }\end{array}$ & 1 cup, cooked (240 g) & 3.12 & 124.8 & $21 \%$ \\
\hline Milk, whole (3.25\%) & 1 cup (244 g) & 3.17 & 124 & $21 \%$ \\
\hline $\begin{array}{l}\text { Yogurt, vanilla, low } \\
\text { fat, fortified with } \\
\text { vitamin D }\end{array}$ & $\begin{array}{l}1 \text { container, } 8 \text { oz ( } 227 \\
\text { g) }\end{array}$ & 2.72 & 107 & $18 \%$ \\
\hline Milk, lowfat (1\%) & 1 cup (246 g) & 2.61 & 104 & $17 \%$ \\
\hline $\begin{array}{l}\text { Cereals ready-to-eat, } \\
\text { fortified (various) }\end{array}$ & 1 cup (12 g) & $1-2.5$ & $40-100$ & $17 \%$ \\
\hline Fortified orange juice & 1 cup (249 g) & 2.49 & 99.6 & $17 \%$ \\
\hline $\begin{array}{l}\text { Soymilk (all flavors), } \\
\text { lowfat, with added } \\
\text { calcium, vitamins A } \\
\text { and D }\end{array}$ & 1 cup (243 g) & 2.43 & 99.6 & $17 \%$ \\
\hline
\end{tabular}

\section{CONCLUSION}

The similarities between COVID-19 and the other respiratory illnesses described in this review are very apparent. The clinical trials involving these respiratory illnesses and supplementation with vitamin D have shown promising results. Across all trials, treatment with vitamin D made patients less susceptible to infection and lowered live bacteria counts, reduced symptoms of illness, increased serum 25(OH)D, and corrected vitamin D deficiency. 
For this reason, vitamin $\mathrm{D}$ acts as a natural alternative to drugs like chloroquine, which was one of the most popular drugs being considered for COVID-19 symptom management and prevention. Chloroquine has been targeted as an effective treatment due to its properties as a weak base, which allows it to diffuse passively into acidic cellular compartments like endosomes. When chloroquine enters these organelles, it becomes protonated and gets trapped inside the organelle. Over time, more and more chloroquine will accumulate within these organelles, increasing the $\mathrm{pH}$ and inhibiting enzymes that require certain $\mathrm{pH}$ conditions to function, preventing the maturation of endosomes. It has previously been observed that SARS-CoV enters cells via $\mathrm{pH}$ and receptor-dependent endocytosis making the antiviral effects of chloroquine a seemingly effective weapon against SARS-CoV. However, the negative effects of this drug greatly outweigh its antiviral capabilities and researchers have consequently been forced to look elsewhere for treatments against COVID-19.

Due to the initially intense focus on creating clinical trials and treatment plans centered around drugs like chloroquine, other potentially effective and safer options for treating symptoms have been ignored, like vitamin D. The defensive mechanisms of vitamin D like the increased production of AMPs such as cathelicidin and defensin and the regulation of cytokine release have comparable benefits to manufactured drugs. These AMPs have the ability to lower viral replication rates, prevent endotoxin activity, reduce inflammation, partake in wound repair, and regulate immunity amongst many other functions related to signaling and defense. Additionally, vitamin D can suppress the expression of inflammatory cytokines that damage tissues in the body, ultimately reducing the symptoms of many respiratory illnesses. Thus, these mechanisms may act as a natural alternative or supplementation to cytostatic drugs and other drugs designed to reduce viral replication or prevent worsening infection.

A study using NHANES (National Health and Nutrition Examination Survey) 2004-2006 serum data showed that $42 \%$ of U.S. adults were deficient in vitamin D. However, there is a much higher rate of vitamin $D$ deficiency in those with darker skin like Black and Latino adults that have $82 \%$ and $62 \%$ deficiency, respectively, within the studied demographic [59]. This is because individuals with darker skin have more melanin. Melanin is a pigment that helps protect the skin from damage by the sun, absorbing UV light and neutralizing free radicals caused by UV radiation. Because people with darker skin have more melanin, their skin is more efficient at absorbing UV light. As a result, they must spend much longer in the sun in order to produce the same amount of vitamin D as someone with lighter skin [57]. In a sense, deficiency in vitamin D is an epidemic that is overlooked, but the correction of these deficiencies can greatly affect the way that individuals contract and recover from illnesses. In a study by Daneshkhah et al., an analysis of the way that vitamin D suppresses cytokine storms in COVID-19 patients revealed that if a population were to have normal (as opposed to low) vitamin D levels, there would be a $15 \%$ reduction in the number of severe COVID-19 cases [31]. Seeing as vitamin D has not been found to have harmful effects even from the consumption of 10,000 IU daily, there is no inherent risk to promoting the increased consumption or supplementation of vitamin D [58]. Additionally, the benefits that vitamin D has been shown to have on a plethora of illnesses, respiratory or otherwise, support the notion that vitamin $D$ should be considered as an important 
candidate for preventing or managing viral infections including those posed by COVID-19.

Under normal circumstances, many people spend most of their days working inside. These work conditions don't facilitate the intake of vitamin D from the sun that is necessary to boost immunity. Due to the conditions of quarantine which require people to stay inside as much as possible, these effects have only become exacerbated. For this reason, it's important to create functional foods that facilitate the necessary intake of vitamin $D$ and encourage diets rich in vitamin D.

List of Abbreviations: 2019 Novel Coronavirus (2019nCoV), World Health Organization (WHO), Coronavirus Disease 2019 (COVID-19), AngiotensinConverting Enzyme (ACE2), Severe Acute Respiratory Syndrome (SARS), Angiotensin II (ANG II), Food and Drug Administration (FDA), Emergency Use Authorization (EUA), Lipopolysaccharide (LPS), Vitamin D Receptor (VDR), Ultraviolet (UV), AntiMicrobial Peptide (AMP), Granulocyte ColonyStimulating Factor (GCSF), Macrophage Inflammatory Protein 1alpha (MIP1A), International Unit (IU), Relative Copy Units (RCU), Atopic Dermatitis (AD), Chron's Disease (CD), Parathyroid Hormone (PTH), Acute Respiratory Distress Syndrome (ARDS), Chronic Obstructive Pulmonary Disease (COPD), Toll-like Receptors 2/1 (TLR2/1), Cytochrome p450 27B1 (CYP27b1), Interleukin-15 (IL-15), National Institutes of Health (NIH), Recommended Daily Allowance (RDA), Institute of Medicine (IOM), National Health and Nutrition Examination Survey (NHANES).

Competing Interests: The authors declare that there are no conflicts of interest.
Author's Contributions: Charlotte Giordano structured the design and implementation of the research and conducted the analysis and writing of the manuscript. Danik Martirosyan helped to conceptualize and structure the article topic and revise the manuscript.

Human and Animal Studies: This article contains descriptions of human studies, all of which were consented and humane. No animal studies were conducted.

\section{REFERENCES}

1. Johns Hopkins, "COVID-19 Dashboard by the CSSE at JHU." ArcGIS Dashboards.

2. National Collaborating Centre for Environmental Health (NCCEH). (2020) An Introduction to SARS-CoV-2. Vancouver, BC: NCCEH.

3. Hamming, I., Timens, W., Bulthuis, M. L. C, Lely, A. T., Navis, G. J., , Goor, H. van (2004). Tissue Distribution of ACE2 Protein, the Functional Receptor for SARS Coronavirus. A First Step in Understanding SARS Pathogenesis. The Journal of Pathology, Vol. 203, no. 2, 631-637.

4. Cui, C., Xu, P., Li, G., Qiao, Y., Han, W., Geng, C., Liao, D., Yang, M., Chen, D., Jiang, P. (2019). Vitamin D Receptor Activation Regulates Microglia Polarization and Oxidative Stress in Spontaneously Hypertensive Rats and Angiotensin II-Exposed Microglial Cells: Role of Renin-Angiotensin System. Redox Biology, Vol. 26, 101295.

5. Tikellis, C., Thomas, M. C. (2012). AngiotensinConverting Enzyme 2 (ACE2) Is a Key Modulator of the Renin Angiotensin System in Health and Disease. International Journal of Peptides, 256294.

6. Gallagher J. C. (2013). Vitamin D and aging. Endocrinology and metabolism clinics of North America, 42(2), 319-332.

7. Office of the Commissioner, U.S. Food and Drug Administration. (2020). "Emergency Use Authorization."

8. Office of the Commissioner, U.S. Food and Drug Administration. (2020) "Coronavirus (COVID-19) Update: FDA Reiterates Importance of Close Patient Supervision for 'Off-Label' Use of Antimalarial Drugs to Mitigate Known Risks, Including Heart Rhythm Problems."

9. World Health Organization, World Health Organization (2020). "Draft Landscape of COVID-19 Candidate Vaccines." 
10. Martirosyan, D., Singh, J. (2015). “A New Definition of Functional Food by FFC: What Makes a New Definition Unique?" Functional Foods in Health and Disease, 5(6): 209-223.

11. Wu, C. Y., Jan, J. T., Ma, S. H., Kuo, C. J., Juan, H. F., Cheng, Y. S., Hsu, H. H., Huang, H. C., Wu, D., Brik, A., Liang, F. S., Liu, R. S., Fang, J. M., Chen, S. T., Liang, P. H., \& Wong, C. H. (2004). Small molecules targeting severe acute respiratory syndrome human coronavirus. Proceedings of the National Academy of Sciences of the United States of America, 101(27), 10012-10017. https://doi.org/10.1073/pnas.0403596101

12. Li, S. Y., Chen, C., Zhang, H. Q., Guo, H. Y., Wang, H., Wang, L., Zhang, X., Hua, S. N., Yu, J., Xiao, P. G., Li, R. S., \& Tan, X. (2005). Identification of natural compounds with antiviral activities against SARSassociated coronavirus. Antiviral research, 67(1), 1823. https://doi.org/10.1016/j.antiviral.2005.02.007

13. Lung, J., Lin, Y. S., Yang, Y. H., Chou, Y. L., Shu, L. H., Cheng, Y. C., Liu, H. T., \& Wu, C. Y. (2020). The potential chemical structure of anti-SARS-CoV-2 RNAdependent RNA polymerase. Journal of medical virology, 92(6), 693-697. https://doi.org/10.1002/jmv.25761

14. Yang, J., Zhang, H., Xu, J. (2016). Effect of vitamin D on ACE2 and vitamin D receptor expression in rats with LPS-induced acute lung injury. Chinese J Emerg Med, 25(12), 1284-1289.

15. Margalith, P. (1989) Vitamin D: The Biotechnology of Ergosterol. In: Vandamme E.J. Biotechnology of Vitamins, Pigments and Growth Factors. Elsevier Applied Biotechnology Series. Springer, Dordrecht.

16. Nair, R., Maseeh, A. (2012). Vitamin D: The "sunshine" vitamin. Journal of pharmacology \& pharmacotherapeutics, 3(2), 118-126.

17. Schwalfenberg, G.K. (2011). A review of the critical role of vitamin $D$ in the functioning of the immune system and the clinical implications of vitamin D deficiency. Mol. Nutr. Food Res, 55, 96-108.

18. Hertting $\mathrm{O}$, Holm A, Luthje $\mathrm{P}$, Brauner $\mathrm{H}$, Dyrdak $\mathrm{R}$, Jonasson AF, et al. (2010) Vitamin D Induction of the Human Antimicrobial Peptide Cathelicidin in the Urinary Bladder. PLOS ONE, 5(12): e15580.

19. Lips P, Hosking D, Lippuner K, Norquist JM, Wehren L, Maalouf $G$, et al. (2006). The prevalence of vitamin D inadequacy amongst women with osteoporosis: An international epidemiological investigation. J Intern Med, 260:245-54.

20. Christakos, S., Dhawan, P., Verstuyf, A., Verlinden, L., \& Carmeliet, G. (2016). Vitamin D: Metabolism, Molecular Mechanism of Action, and Pleiotropic Effects. Physiological reviews, 96(1), 365-408.

21. Klick Health. (2020). COVID-19 Virus 3D Model.

22. Hargrove, L., Francis, T., Francis, H. (2014). Vitamin D and $\mathrm{Gl}$ cancers: shedding some light on dark diseases. Ann Transl Med, 2(1):9.
23. Sirajudeen, S., Shah, I., Menhali, A. (2019). A narrative role of vitamin D and it's receptor: with current evidence on the gastric tissues. Int. J. Mol. Sci, 20(15), 3832.

24. Yang, D., Chertov, O., Oppenheim, J. J. (2001). Participation of mammalian defensins and cathelicidins in anti-microbial immunity: receptors and activities of human defensins and cathelicidin (LL-37). Journal of Leukocyte Biology, 69(5), 691-697.

25. Martinez-Moreno, J., Hernandez, J.C., Urcuqui-Inchima, S. (2020). Effect of high doses of vitamin D supplementation on dengue virus replication, Toll-like receptor expression, and cytokine profiles on dendritic cells. Mol. Cell. Biochem. 464, 169-180.

26. Zanetti M. (2005). The role of cathelicidins in the innate host defenses of mammals. Curr Issues Mol Biol, 7:179196.

27. Kosciuczuk, E. M., Lisowski, P., Jarczak, J., Strzalkowska, N., Jozwik, A., Horbanczuk, J., Krzyzewski, J., Zwierzchowski, L., Bagnicka, E. (2012). Cathelicidins: family of antimicrobial peptides. A review. Molecular Biology Reports, 39(12), 10957-10970.

28. Hiemstra, P.S. (2006). Defensins. Encyclopedia of Respiratory Medicine, 8-10.

29. Cytokine Function. Sino Biological. [https://www.sinobiological.com/resource/cytokines/c ytokine-function]

30. Huang, C., Wang, Y., Li, X., Ren, L., Zhao, J., Hu, Y., Zhang, L., Fan, G., Xu, J., Gu, X., Cheng, Z., Yu, T., Xia, J., Wei, Y., Wu, W., Xie, X., Yin, W., Li, H., Liu, M., Xiao, Y., Gao, H., Guo, L., Xie, J., Wang, G., Jiang, R., Gao, Z., Jin, Q., Wang, J., Cao, B. (2020). Clinical features of patients infected with 2019 novel coronavirus in Wuhan, China. The Lancet, 395 497-506.

31. Daneshkhah, A., Eshein, A., Subramanian, H., Roy, H.K., Backman, V. (2020). The role of vitamin D in suppressing cytokine storm in COVID-19 patients and associated mortality. medRxiv.

32. Hata, T. R., Kotol, P., Jackson, M., Nguyen, M., Paik, A., Udall, D., Kanada, K., Yamasaki, K., Alexandrescu, D., \& Gallo, R. L. (2008). Administration of oral vitamin D induces cathelicidin production in atopic individuals. The Journal of Allergy and Clinical Immunology, 122(4), 829-831.

33. Raftery, T., Martineau, A.R., Greiller, C.L., Ghosh, S., McNamara, D., Bennett, K., Meddings, J., O’Sullivan, M. (2015). Effects of vitamin D supplementation on intestinal permeability, cathelicidin and disease markers in Crohn's disease: results from a randomized double-blind placebo-controlled study. United European Gastroenterology J, 3(3), 294-302.

34. Chandra, P., Binongo, J.N., Ziegler, T.R., Schlanger, L.E., Wang, W., Someren, J.T., Tangpricha, V. (2008). Cholecalciferol (vitamin D3) therapy and vitamin D insufficiency in patients with chronic kidney disease: a randomized controlled pilot study. Endocrine Practice: Official Journal of the American College of 
Endocrinology and the American Association of Clinical Endocrinologists, 14(1), 10-17.

35. Trivedi, D.P., Doll, R., Khaw, K.T. (2003). Effect of four monthly oral vitamin D3 (cholecalciferol) supplementation on fractures and mortality in men and women living in the community: randomized doubleblind controlled trial. BMJ, 326, 469.

36. Lappe, J.M., Travers-Gustafson, D., Davies, K.M., Recker, R.R., Heaney, R.P. (2007). Vitamin D and calcium supplementation reduces cancer risk: results of a randomized trial. The American Journal of Clinical Nutrition, 85(6), 1586-1591.

37. Harvard Bioscience Inc. (2020). Acute Disorders. Acute Respiratory Disorders.

38. Aygun, H. (2020). Vitamin D can prevent COVID-19 infection-induced multiple organ damage. NaunynSchmiedeberg's Archives of Pharmacology, 393(7), 1157-1160.

39. Bergman, P., Norlin, A.C., Hansen, S., Rekha, R.S., Agerberth, B., Bjorkhem-Bergman, L., Ekstrom, L., Lindh, J.D., Andersson, J. (2012). Vitamin D3 supplementation in patients with frequent respiratory tract infections: a randomised and double-blind intervention study. BMJ Open, 2(6), e001663.

40. Vargas Buonfiglio, L.G., Cano, M., Pezzulo, A.A., Vanegas Calderon, O.G., Zabner, J., Gerke, A.K., Comellas, A.P. (2017). Effect of vitamin D3 on the antimicrobial activity of human airway surface liquid: preliminary results of a randomised placebo-controlled double-blind trial. BMJ Open Respiratory Research, 4(1), e000211.

41. Laaksi, I., Ruohola, J., Mattila, V., Auvinen, A. Ylikomi, T., Pihlajamaki, H. (2010). Vitamin D Supplementation for the Prevention of Acute Respiratory Tract Infection: A Randomized, Double-Blinded Trial among Young Finnish Men. The Journal of Infectious Diseases, 202(5), 809814.

42. Martineau, A.R., Wilkinson, R.J., Wilkinson, K.A., Newton, S.M., Kampmann, B., Hall, B.M., et al. A single dose of vitamin $D$ enhances immunity to mycobacteria. Am J Respir Crit Care Med, 176, 208-213.

43. Manaseki-Holland, S., Qader, G., Isaq Masher, M., Bruce, J., Zulf Mughal, M., Chandramohan, D., Walraven, G. (2010). Effects of vitamin D supplementation to children diagnosed with pneumonia in Kabul: a randomised controlled trial. Tropical Medicine \& International Health: $T M$ \& $I H$, 15(10), 1148-1155.

44. Lehouck, A., Mathieu, C., Carremans, C., Baeke, F., Verhaegen, J., Van Eldere, J., Decallonne, B., Bouillon, R., Decreamer, M. (2012). High doses of vitamin D to reduce exacerbations in chronic obstructive pulmonary disease: a randomized trial. Annals of Internal Medicine, 156, 105-14.

45. Martineau, A.R., James, W.Y., Hooper, R.L., Barnes, N.C. Jolliffe, D.A., Greiller, C.L., Islam, K., McLaughlin, D., Bhowmik, A., Timms, P.M., et al. Vitamin D3 supplementation in patients with chronic obstructive pulmonary disease (ViDiCO): A multicentre, doubleblind, randomized controlled trial. Lancet Respir. Med. 3, 120-130.

46. Aloia, J. F., Li-Ng, M. (2007). Re: epidemic influenza and vitamin D. Epidemiology and infection, 135(7), 10951098.

47. Urashima, M., Segawa, T., Okazaki, M., Kurihara, M., Wada, Y., Ida, H. (2010). Randomized trial of vitamin D supplementation to prevent seasonal influenza $A$ in schoolchildren, The American Journal of Clinical Nutrition, 91(5), 1255-1260.

48. CDC. (2019). Types of Influenza Viruses. Centers for Disease Control and Prevention.

49. Smith, I. (2003). Mycobacterium tuberculosis pathogenesis and molecular determinants of virulence. Clinical Microbiology Reviews, 16(3), 463496.

50. Keane, J., Balcewicz-Sablinska, M.K., Remold, H.G., et al. (1997). Infection by Mycobacterium tuberculosis promotes human alveolar macrophage apoptosis. Infect Immun. 65(1), 298-304.

51. Krutzik, S.R., Hewison, M., Liu, P.T., et al. (2008). IL-15 links TLR2/1-induced macrophage differentiation to the vitamin D-dependent antimicrobial pathway.J Immunol. 181(10), 7115-7120.

52. Adams, J.S., Chen, H., Chun, R., et al. (2007). Substrate and enzyme trafficking as a means of regulating 1,25dihydroxyvitamin $D$ synthesis and action: the human innate immune response. J Bone Miner Res. 22 Suppl 2: V20-V24.

53. Jain, V., Vashisht, R., Yilmaz, G., et al. (2020) Pneumonia Pathology. StatPearls Publishing.

54. USDA, National Institutes of Health. (2020). Vitamin D: fact sheet for consumers.

55. Aloia, J.F., Patel, M., Dimaano, R., et al. (2008).Vitamin $D$ intake to attain a desired serum 25-hydroxyvitamin D concentration. Am J Clin Nutr, 87(6), 1952-1958.

56. Ross, A.C., Manson, J.E., Abrams, S.A., et al. (2011). The 2011 report on dietary reference intakes for calcium and vitamin D from the Institute of Medicine: what clinicians need to know. J Clin Endocrinol Metab, 96(1), 53-58.

57. Cicarma, E., Porojnicu, A.C., Lagunova, Z., Dahlback, A., Juzeniene, A., Moan, J. (2009). Sun and Sun Beds: Inducers of Vitamin D and Skin Cancer. Anticancer Research, 29(9), 3495-3500.

58. Hathcock, J. N., Shao, A., Vieth, R., \& Heaney, R. (2007). Risk assessment for vitamin D. The American journal of clinical nutrition, 85(1), 6-18. https://doi.org/10.1093/ajcn/85.1.6

59. U.S. Department of Agriculture: Agricultural Research Service (2019-2020). FoodData Central.

60. Kimberly, Y.Z., Forrest, W.L.S. (2011). Prevalence and correlates of vitamin D deficiency in US adults. Nutrition Research, 31(1), 48-54. 